\title{
Insights into responsible education for sustainable development : the case of UWE, Bristol
}

\section{Svetlana Cicmil, Georgina Gough and Sarah Hills}

all authors at University of the West of England, Bristol, Coldharbour Lane, Bristol, BS16 1QY.

Corresponding Author: Svetlana Cicmil, UWE Bristol, Coldharbour Lane, Bristol, BS16 1QY.

Svetlana.Cicmil@uwe.ac.uk

Key words: axioms of education for sustainable development; management education; sustainable universities; pedagogic complexities.

\begin{abstract}
In this paper, we argue that it is opportune to revisit profound questions about the purpose, nature and value of higher education in society at a juncture where the context of higher education has been significantly influenced by the global sustainability agenda and responsible management education imperatives (United Nations (UN) Principles of Responsible Management Education (PRME), UN Sustainable Development Goals (SDGs), UN Global Compact, UN Decade of Education for Sustainable Development (ESD), etc.). We take Holman's (2000) work on models for management education and his recommendations as our point of departure in critically examining the practice of embedding ESD and UN PRME (as two complementary schemes) in our institution. We explore the nature and interrelationships of Holman's 5 axioms of management education (epistemic, pedagogical, management-as-practice, social, and organisational) in order to provide a reflective account of our experiences and elucidate deeper understandings of what responsible education for sustainable development may mean in practice. The arguments presented here are grounded in both practical theorising stemming from related literature and concrete empirical illustrations generated through our observations and reflections as participants (in our roles as PRME Leader, ESD champion and SD programme leader) in the PRME/ESD initiatives. We have demonstrated that embedding ESD responsibly across a $\mathrm{HE}$ institution is a complex, emerging, evolving and non-linear process of addressing simultaneously the curriculum content, power, structures, identity, values, and external checks and balances. Therefore, a critical attention is needed to all 5 axioms and assumptions that are at play and has to be facilitated by a combination of educational activism, informal academic collaboration, formal measures and reporting, and practical skills of maintaining legitimacy and ownership of creative and innovative pedagogic models while negotiating the meaning of those to align with the institutional priorities.
\end{abstract}




\section{Introduction}

In the very call for papers for this special issue (SI) it is stated that "university business schools are in a unique position to influence the mindsets and actions of some of the largest organisations on the planet" (emphasis ours) amid the initiatives of integrating the Principles of RME and the post-2015 SDGs across HE curricula. Inspired by the UN PRME mission to take the case for universal values ... into classrooms on every continent (emphasis ours), it is also opportune to reflect on these experiences so far by more explicitly considering the purpose, nature and value of university education as a social, political and intellectual practice, including but not limited to University Business and Management Schools or Departments. This is the key rationale behind our paper.

Sustainability / sustainable development related debates at local and global levels in the public sphere including education, law, policy making and political-social-economic negotiations have been argued from multiple points of view, are value -laden and represent the interests of many groups and communities (Painter-Morland, Sabet, Molthan-Hill, Goworek, and de Leeuw, 2016; Curry, 2011, Hutchings, 2010, Gladwin, Kennelly and Krause, 1995). The proposed solutions to the global sustainability crisis are consequently often seen as controversial, fragmented and with adverse consequences on equality and global justice, confirming that, as Gladwin et al., (1995) predicted, "the notion of sustainable development will remain fuzzy, elusive, contestable, and/or ideologically controversial for some time to come" (p. 876).

In practice then, education for sustainability is bound to reflect the fragmented nature of the sustainability/SD field itself, inhabited by a range of often competing models, theories, methods and arguments. Variability in practice and multiple definitions of the sustainability crisis make it impossible to defend one 'best way' of educating for SD and agreeing the priorities at a global level (Cicmil, Ecclestone and Collins, 2017). Contested and competing definitions, paradigms and concepts exist because 'sustainability' is a moral and political, as well as a scientific, phenomenon which means it cannot be fully empirically justified and tested, but has to be inter-subjectively negotiated (Gladwin et al., 1995). Therefore, we must also note the profound importance of how one speaks and thinks about it and the need for transparency of the underlying interests and agendas (e.g. Flyvbjerg, 1998 and 2001, Holman, 2000) as this, in turn, develops a capacity to understand and respect that there may be other, equally valid and justifiable positions on the same problem. Equally importantly, willingness to search for a common ground amid the diversity needs to be encouraged in collective negotiations of acceptable ways forward, where solidarity, equality, interdependency, safety, connectivity and prudence are explicitly taken as critical benchmarks (Gladwin et al., 1995). The above arguments form a strong message for educators and universities about what the notion of responsible education (for sustainable development) should entail in practice if we are to practice it responsibly and in a way that matters for diverse groups of educational stakeholders affected by it (c.f. Solitander, Fougère, Sobczak, and Herlin, 2012; Painter-Morland, 2015; Painter-Morland, et al. 2016).

In this paper, we use David Holman's (2000) examination of the assumptions behind contemporary models of management education in the UK as the basis for our discussion. As his point of departure, Holman considered questions which had historically underpinned debates about the purpose, nature and value of universities more generally: What is the role of higher education in society? What types of knowledge should a higher education pursue? What is learning, and what 
should count as ideal outcomes of that process? How should universities be managed? This paper argues that these questions have been made all the more pertinent by the growing influence of the global sustainability agenda and responsible management education imperatives, such as PRME.

The field of responsible management education (RME) has emerged since Holman's framework was published and many authors have explored issues corresponding to and resonating with, individual components of Holman's framework. The literature so far has almost exclusively addressed the context of business schools (reflecting the original intention of PRME) and with the objective of identifying barriers to progressing RME practice beyond just small adjustments to curriculum content (e.g. Cornuel and Hommel, 2015; Karakas, Sarigollu, and Manisaligil, 2013). The pedagogic axiom has perhaps received most attention, both in the literature and in practice (Louw, 2015). Godemann, Haertle, Herzig and Moon (2014) commented, in their review of SIP reports, that most institutions are addressing PRME through teaching, rather than through institutional action.

Resonating the above identified complexities, this paper ultimately aims to contribute to the efforts of creating, in a responsible way, effective educational strategies for developing self-aware, confident and caring global citizens some, if not most, of whom will at some point in their career assume a managerial or leadership role. The University of the West of England (UWE), Bristol offers a relevant and unique study context with its experience of embedding ESD and UN PRME (as two complementary schemes) and insights into practices at individual programme level but also across its UG and PG provision and at cross-institutional level. The alignment between responsible management education and the focus on education for sustainable development (in all components of UWE educational provision), within a framework of more general management education, is the unique aspect of this case, empirically and conceptually (c.f. Burchell, Kennedy, and Murray, 2015).

The paper unfolds as follows: We briefly outline Holman's (2000) discussion of assumptions contained with management education grouped into 5 axioms and his recommendations of alternative education models most appropriate to responsibly reflect complex realities of, and lived experiences with managerial work in practice. This is, then used as a framework for structuring and presenting a critical examination of practice related to ESD and UN PRME (as two complementary schemes) in our institution (Sections 3 and 4). Methodological aspects of our study including its design and the sources of data used are also discussed. Section 5 provides the reader with an insight into the relative significance and interrelationships between each of Holman's five axioms as played out in ESD/RME practices at UWE, Bristol to illuminate progress made, challenges and useful ways forward for future practice. We finish with a set of academic and practical propositions for future work and research.

\section{Responsible management education and education for sustainable development - Conceptual propositions}

We start this section by outlining Holman's (2000) discussion of assumptions grouped as 5 axioms an epistemic, a pedagogical, a management-as-practice, a social, and an organisational/institutional (Table 1) which, he argues, underpin contemporary management education practices in Britain. Holman's critical insights into the interdependences between these axioms and the processes 
through which they always and simultaneously create, and are shaped and reproduced by, contemporary models of management education are, in our view, relevant and helpful in making sense of PRME and ESD implementation. We are particularly interested in Holman's recommendations of alternative education models (such as critical experiential ones) which, he argues, more responsibly reflect complex ambiguous realities of, and lived experiences with, managerial work in practice (c.f. Painter-Morland, et al., 2016).

Table 1 A summary of Holman's (2000) critical analysis of the field of management education in UK HE institutions using 5 axioms

\begin{tabular}{|c|c|c|}
\hline Axiom & Assumptions & $\begin{array}{l}\text { Debates and competing positions (dominant current } \\
\text { ones vs alternative ones) }\end{array}$ \\
\hline Epistemological & $\begin{array}{l}\text { about the nature of } \\
\text { knowledge pursued }\end{array}$ & $\begin{array}{l}\text { e.g. objectivism vs relativism; positivism (e.g. natural } \\
\text { science) vs hermeneutics/phenomenology (e.g. cultural } \\
\text { studies) vs critical school/postmodernism (critical } \\
\text { management studies) }\end{array}$ \\
\hline $\begin{array}{l}\text { Management- } \\
\text { as-practice }\end{array}$ & $\begin{array}{l}\text { about the nature of } \\
\text { management } \\
\text { practice }\end{array}$ & $\begin{array}{l}\text { e.g. rational/technical/functionalist vs } \\
\text { processual/relational vs critical ethical praxis }\end{array}$ \\
\hline Social & $\begin{array}{l}\text { about the perceived } \\
\text { role of business and } \\
\text { management } \\
\text { education in society: } \\
\text { - vocational role } \\
\text { - academic role } \\
\text { - critical role } \\
\text { - cultural role }\end{array}$ & $\begin{array}{l}\text { e.g. choosing / reconciling assumptions behind } \\
\text { - vocational: 1) knowledge and skills directly meeting the } \\
\text { requirements of occupational groups/organisations and } \\
\text { /or 2) developing competencies resulting from a broader } \\
\text { inquiry into management and organisation not } \\
\text { necessarily immediately corresponding to those defined } \\
\text { by organisations } \\
\text { - academic: focused on increasing knowledge and } \\
\text { understanding about the organisations and management } \\
\text { education } \\
\text { - critical: develops and encourages the skill for critical } \\
\text { enquiry into the status quo of management practice and } \\
\text { education, and society at large, as a legitimate outcome } \\
\text { of higher education } \\
\text { - indirect cultural: produces capable and cultivated } \\
\text { citizens able to lead personally fulfilling lives and help } \\
\text { sustain a democratic and learned culture }\end{array}$ \\
\hline Pedagogical & $\begin{array}{l}\text { about the nature of } \\
\text { the learning process, } \\
\text { its ideal outcomes, } \\
\text { and teaching } \\
\text { methods }\end{array}$ & $\begin{array}{l}\text { e.g. choosing / reconciling assumptions behind } \\
\text { - academic vs experiential theories of learning } \\
\text { - social and identity related constraints in the process of } \\
\text { learning and autonomous development } \\
\text { - use of reflection, reconceptualization and action by } \\
\text { educators and students } \\
\text { - prioritising among outcomes: emancipation, autonomy, } \\
\text { required skills and attributes }\end{array}$ \\
\hline Organisational & $\begin{array}{l}\text { referring to the } \\
\text { management and } \\
\text { organisation of } \mathrm{HE}\end{array}$ & $\begin{array}{l}\text { e.g. } \\
\text { - the degree to which a university can exercise autonomy } \\
\text { over the process and content of management education } \\
\text { and the level of involvement/influence of other }\end{array}$ \\
\hline
\end{tabular}




\begin{tabular}{|l|l|}
\hline & $\begin{array}{l}\text { stakeholders; } \\
\text { - the management of the institution itself } \\
\text { - the accountability of management educators }\end{array}$ \\
\hline
\end{tabular}

Holman's critical evaluation of the 4 suggested broad models of management education - 'academic liberalism, experiential liberalism, experiential vocationalism and experiential/critical school' (2000, p.204) - reveals that the dominant belief in an objective epistemology among (management) educators may not be effective in enabling the "complexity and non-mechanistic nature of managerial practice to be fully addressed" (Holman, 2000, p.209). Equally fundamentally, Holman suggests that alternative pedagogies (e.g. experiential critical) to those which currently prevail could be more beneficial for developing managers better suited to the complex and changing world in which both higher education and its graduates' prospects are located. Not only do they provide an eclectic range of teaching practices which recognise on-the-job learning and reflection, they also legitimise and encourage critique of the very object of the study (organisational management) "which is as it should be in higher education" (ibid., p.210). Alternative pedagogies and epistemologies encourage educators to reflect on their own practice, creating a space for developing ethical practical wisdom (e.g. Flyvbjerg, 2001); and critical hermeneutic epistemology (e.g. Introna, 1997; Segal, Rolfe and Cicmil 2016); the pursuit of university autonomy and resistance to bureaucratisation and commodification of academic work etc. (e.g. Hibbert, 2013). In order to develop these approaches of good practice, Holman suggests that it would be necessary (and responsible) to address, in a transparent way, the nature and the role of identity in learning and teaching, of epistemological uncertainty, the role of narrative and non-narrative, critical thinking and "alternative forms of knowing" (Holman,2000, p.210).

Considering the role which HEls could/should play in addressing complex global sustainable development challenges, we argue that responsible management education as an aspiration, is more likely to be attained / lived up to when based on educational models which resonate with the assumptions of experiential critical pedagogies (as explained above and highlighted in Table 1). However, as Holman concluded, a responsible pedagogic action must acknowledge complex interrelationships and interdependencies between the axioms and must be supported by a profound understanding that a range of possible and conflicting assumptions behind each of the axioms are always present simultaneously enabling and constraining the practice. The benchmarks of 'responsible' education adopted in the paper imply that it is relevant to a non-homogenous group of learners, practitioners and contexts with varying agendas, values and interest (in a global world); ethical deliberations are included, problems with epistemic hegemony are critically exposed to allow true multi-disciplinarity, and scope for dialogue and negotiation of common ground pedagogically and organisationally enabled.

We will now consider the way in which groupings of assumptions aligned to each of Holman's axioms (Table 1) can form a helpful analytical tool for examining the practice of ESD (as an agenda with closely aligned objectives to RME) implementation at a university and illuminating practical and theoretical propositions about how ESD might be progressed. 


\section{Empirical context and method: Education for Sustainable Development and PRME at UWE Bristol}

Education for Sustainable Development (ESD) in the UK higher education sector is the focus of two recent policy documents published by organisations responsible for the regulation and financing of higher education (Quality Assurance Agency (QAA) and the Higher Education Academy (HEA), 2014; Higher Education Funding Council for England (HEFCE), 2014). These documents highlight the importance of the HE sector in leading society towards more sustainable forms of development and, in the case of the QAA-HEA document, provided guidance on what ESD best practice looks like. These documents were both produced with significant consultation of the HE sector and its stakeholders and so present a position which reflects recent thinking about the role of higher education in society.

The stated objectives of the ESD (as articulated in the QAA-HEA ESD Guidance, QAA-HEA, 2014) are closely aligned to the objectives or UN PRME. ESD should encourage students to:

- consider what the concept of global citizenship means in the context of their own discipline and in their future professional and personal lives;

- consider what the concept of environmental stewardship means in the context of their own discipline and in their future professional and personal lives;

- think about issues of social justice, ethics and wellbeing, and how these relate to ecological and economic factors; and,

- develop a future-facing outlook; learning to think about the consequences of actions, and how systems and societies can be adapted to ensure sustainable futures.

UN PRME encourages management education providers to commit to ensuring that the purpose, values, method, research, partnership and dialogue are framed within the context of promoting the globally socially responsible and sustainable corporations, rather than students. ESD considers the content, delivery and context of the educational process. At one level, "education for sustainable development means including key sustainable development issues into teaching and learning" (UNESCO, 2016, online) although this context is sometimes referred to as education about sustainable development, rather than for sustainable development. Indeed, UNESCO (2014b) include content as only one dimension of ESD (the other being pedagogy and learning environments, learning outcomes and societal transformation). Education for sustainable development will reflect the principles of sustainable development in its design and delivery (this should include educational legislation, policy, finance, curriculum, instruction, learning, assessment, etc.) (UNESCO, 2016a, online). "Participatory learning processes, critical thinking and problem-based learning are proving particularly conducive to ESD" (UNESCO, 2014a, p7).

UWE, Bristol is a large, multi-campus university with UG, PG and research portfolios spanning numerous disciplines. Its Strategy 2020 document outlines its ambition to be inclusive and global in outlook and approach and reinforces its focus on practice-oriented learning (UWE, 2016). The university's commitment to being a sustainable and responsible organisation is articulated both in the institutional strategy and in UWE's Sustainability Plan (2013-2020) (UWE, 2013). UWE's education for sustainable development (ESD) work has developed over the past twenty years; from a baseline curriculum survey and discussion/action group for interested staff to an institutional 
priority. At UWE ESD has been understood and promoted not as an add-on but as a core activity for all university stakeholders.

UWE Bristol has also recognised the close alignment between ESD and PRME and taken on PRME as an institution-wide initiative, using its long-standing ESD work at the vehicle by which to progress PRME. UWE sees its ESD engagement and long-standing active membership of and contribution to UN PRME as being the right thing to do but also having the potential to contribute to other institutional drivers such as student and staff satisfaction and graduate employability (c.f. Burchell, et al 2015).

We, the authors, have been closely involved in leading, delivering and facilitating both ESD and management education across the institution over a period of eight years. The experience has been enlightening and rewarding and our efforts continue with a renewed attention brought about by the recent agreement of and subsequent global action on the UN Sustainable Development Goals. It is opportune at this junction to reflect on and make sense of the process of embedding both PRME and ESD at UWE and to do so within a framework which allows a holistic critical examination of multiple aspects of such a process, its challenges, dilemmas and unsolved issues. This has been called for in recent literature (e.g. Cornuel and Hommel, 2015). Holman's (2000) critique of dominant assumptions behind models of management education has offered a framework within which to conduct our analysis of what is recognised to be a 'fragmented field' (ibid., p.209).

\subsection{Research Design}

The empirical data was generated through our observations as participants in the PRME/ESD initiatives at UWE. Our work represents an action research approach which has been undertaken with a view to enabling us not only to reflect on our experiences and that of our institution, but also to undergo transformational learning leading to a better understanding of "the tensions and contradictions affecting (our) practices, at an individual, organizational and structural level and the need to collectively to develop strategies to challenge these problems and even to reconfigure them" (Eady, Drew and Smith, 2015, p106). We are embedded in the ESD community with our institution and have thus been able to collect data on policy development and practice of ESD. This data consists of institutional documents, curriculum documents, minutes of meetings and committees and personal notes of our experiences as members of UWE's ESD implementation activity. Our observations of practice, and critically, of the influences which drive and shape this practice, form the basis of our interpretation of the interrelationships between Holman's axioms in the context of ESD. We represent a diversity of academic disciplinary areas and hierarchies, international experience and cultural and professional backgrounds and thus are confident that our observations represent a valid account of practice.

Whilst subjectivity is acknowledged to be a limitation of this approach (a combination of action research design and participant observation method), transparency in the process of data interpretation provides mitigation against the potential for biased conclusions to be drawn. The validity and reliability of the data are controlled by virtue of the cross-institutional roles which we hold and by the fact that observations were made across a variety of settings, over a period of years, and in relation to a wide cross-section of university of activity. A limitation of the work is that observations have been made within a particular time frame (2009-2016) and by a relatively small 
number of researchers (relative to the number of staff involved in the delivery of RME and ESD within the institution).

\subsection{The method of data interpretation}

Holman's work provides a well-defined framework to reflect on UWE's approach to both embracing ESD and grounding its institution-wide adoption of UN PRME within its ESD activity. The two initiatives have instigated major resource-demanding changes and innovations in higher education for at least a decade, and have been promoted in various ways by international (UN) and local (QAA) policy-making bodies. As explained previously, Holman's original propositions call for more effective and beneficial models of management education in a complex socio-political and economic national context. Moreover, his analytical framework of assumptions behind the 5 axioms of higher education resonate well with the stipulated ideals and vision of education for sustainability outlined above. We have filtered our empirical evidence through the lens of the 5 axioms and collectively negotiated the assumptions behind the observed actual practices in the process of constructing Table 2. This collective sense-making (an organic part of participant observation in action research) was informed by our own understanding of Holman's work as well as our diverse individual positions on sustainability and sustainable development (mentioned in the preceding section). The left-hand side column contains our reinterpretation of that framework in the context of ESD thus expanding its original use for management education to embrace ESD. The right-hand side column indicates key issues observed. We acknowledge that the relative influence of individual axioms on practice is negotiable, context-dependent and emergent in nature, deriving from formal and informal conversations amongst colleagues. Thus, our observations of the influence which these have had in recent years at UWE, may not hold true in future years or at other institutions.

\section{Uncovering assumptions behind observed practices of ESD /PRME at UWE Bristol}

The framework of five axioms used by Holman to explore the assumptions underpinning management education encourages a holistic view to be taken of university systems and consideration to be made of the simultaneous influence each axiom has in building higher education as practice. Our evaluation of the integration of ESD and PRME into one HEI using the axioms as a guide has generated insights into an inherent interdependence of the assumptions behind the epistemic, organisational, social, pedagogical and practice dimensions of the given field. We summarise (Table 2) these insights, leading to a critical discussion of models of education and the extent to which they live up to the notion of responsible education of future managers and leaders towards a fairer, more sustainable and prosperous world for all.

Table 2 here 
Table 2 Insights into ESD implementation

\begin{tabular}{|c|c|c|}
\hline & \multicolumn{2}{|c|}{ Key issues, challenges and dilemmas related to ESD arising from a } \\
\hline & \multicolumn{2}{|c|}{$\begin{array}{l}\text { - the extent to which the relationship between knowledge, power, perception and interests are } \\
\text { - addressed: e.g. deep green vs week sustainability } \\
\text { - perception of 'academic freedom' linked to activism (by both students and lecturers) } \\
\text { - certain subject areas are more conducive to embracing ESD } \\
\text { - sustainability is dialogically negotiated in discussion with practitioners (sustainability champions in } \\
\text { their organisations) } \\
\text { - epistemological plurality in understanding the sustainability crisis; power asymmetries between } \\
\text { definitions; discourses and agendas }\end{array}$} \\
\hline & \multicolumn{2}{|c|}{$\begin{array}{l}\text { - emphasis on practical knowledge and employability in a global context } \\
\text { - range of behaviours evident from functional / compliance based (technicist-scientific-eco-efficiency) to } \\
\text { innovation driven stewardship and resource constrained operations; to activism and social advocacy } \\
\text { for radical transformation } \\
\text { - difficulty in reconciling diverse and conflicting voices regarding the urgency and priorities; power } \\
\text { asymmetries between agendas; ethics and values always present } \\
\text { ambiguity around what is considered as good practice and which values, views and KPIs should be } \\
\text { prioritised }\end{array}$} \\
\hline \multicolumn{2}{|c|}{$\begin{array}{l}\text { Social } \\
\text { vocational role (provides the necessary knowledge } \\
\text { and skills to sustain a competitive economy while } \\
\text { mitigating the sources of sustainability crisis) } \\
\text { academic role (increased knowledge and } \\
\text { understanding of sustainable development and ESD) } \\
\text { critical role (opens up some scope for critiques of } \\
\text { business management and professions and their } \\
\text { impact on ecological crisis and conduct with } \\
\text { reference to inequalities, injustice and power }\end{array}$} & $\begin{array}{l}\text { of sustainable development and professional practice but also developing } \\
\text { competencies resulting from a broader inquiry into the sustainability agenda, not } \\
\text { necessarily immediately corresponding to those defined above (e.g. leadership; } \\
\text { behavioural change, communication) } \\
\text { - academic: focused on increasing knowledge and understanding about the } \\
\text { sustainability crisis, the global sustainability agenda, SD and sustainability } \\
\text { education, and the role of professions, organisations, individuals and government } \\
\text { in creating pro-sustainability change and management education } \\
\text { - critical: develops and encourages the skills for critical enquiry into the status quo } \\
\text { of management practice and education, and society at large, as a legitimate }\end{array}$ \\
\hline
\end{tabular}




\begin{tabular}{|c|c|c|}
\hline \multicolumn{2}{|c|}{$\begin{array}{l}\text { structures in contemporary global social order ) } \\
\text { cultural role (addressing values and aspirations } \\
\text { which are relevant to developing 'capable and } \\
\text { cultivated citizens who are able to lead personally } \\
\text { fulfilling lives and help sustain a democratic and } \\
\text { learned culture' (Holman. p.200) }\end{array}$} & $\begin{array}{l}\text { outcome of ESD } \\
\text { indirect cultural: related to the culture of HE and the academic community with } \\
\text { regard to subject specialism and disciplinarity. Challenges exist in the } \\
\text { development of knowledge, skills and ethical vocabulary necessary for modes of } \\
\text { critical dialogue and forms of a broadened civic participation.' }\end{array}$ \\
\hline $\begin{array}{l}\text { Pedagogical } \\
\text { Assumptions about the nature of } \\
\text { ESD, its ideal outcomes, and } \\
\text { teaching methods }\end{array}$ & \multicolumn{2}{|c|}{$\begin{array}{l}\text { - both approaches to knowledge and learning are in use simultaneously: academic and subjective } \\
\text { experiential } \\
\text { definition of learning outcomes seems to be influenced by ESD guidance and the language of the } \\
\text { institution, but subtly, and across different subject areas, the following ideal outcomes seem to be } \\
\text { applied: emancipation, autonomy, hard sustainability skills and attributes } \\
\text { - reflection, reconceptualization and action are used (by both educators and students) in a number of } \\
\text { modules, including practice-based learning and critical participatory pedagogy. } \\
\text { concerns about learning processes in a culturally diverse / international class have been seen as } \\
\text { important }\end{array}$} \\
\hline $\begin{array}{l}\text { Organisational } \\
\text { Referring to the management } \\
\text { and organisation of HE and the } \\
\text { given University (organising } \\
\text { processes, actors, structures, and } \\
\text { governance) with reference to } \\
\text { commitment to the sustainability } \\
\text { agenda and responsible } \\
\text { management. Who can influence } \\
\text { the process and content of } \\
\text { ESD/RME and to what degree? }\end{array}$ & \multicolumn{2}{|c|}{$\begin{array}{l}\text { - degree to which a university can exercise autonomy over the process and content of ESD: a growing } \\
\text { body of evidence shows that, increasingly, the compliance with the national policies and guidelines, } \\
\text { accreditations and audits compromises the level of (desired) autonomy of the institution itself and its } \\
\text { academics. Level of involvement/influence of other (external) agencies such as QAA and professional } \\
\text { accreditation bodies is of relevance. } \\
\text { management of the institution (UWE) itself: our evidence shows that the institution has taken the } \\
\text { ESD and sustainability agendas very seriously, driven by the desire to 'do the right thing' and by } \\
\text { competition due to the involvement and influence of other stakeholders }\end{array}$} \\
\hline
\end{tabular}




\subsection{The epistemological axiom and responsible education for sustainable development}

The epistemological axiom presents a critical challenge for ESD in HE. The multidisciplinary nature of approaches needed to understand and develop solutions to sustainable development challenges is troublesome for the often single-disciplinary nature of HE departments. Approaches from science, technology, sociology, politics and economics meet and clash in, often, irreconcilable ways, when considering sustainable development issues (see the introductory section). Within UWE, there has been some resistance to the notion of institution-wide inclusion of sustainability into the curriculum, primarily by colleagues who see sustainable development as a value set (favouring proenvironmental or pro-social positioning) and who also feel that it is wrong to teach values. In response to concerns, ESD guidance for staff has been developed to more clearly articulate the expectations of both external bodies, such as the QAA and professional accreditation bodies, and the institution to ensure that what is common is that students are provided with information about the state of the world, are made aware of global sustainability challenges and are given the opportunity, as appropriate to their discipline, to consider and debate solutions which might derive from their professional practice or, possibly, to debate the nature of the problems.

The QAA-HEA ESD Guidance uses the language of outcomes - knowledge, skills and attributes - to set objectives of ESD. UWE's portfolio of research and degree programmes includes disciplines which focus on widely-promoted sustainability issues (such as climate change and environmental degradation) and their management. Each are underpinned by a specific set of assumptions regarding the 'epistemology' of the subject area and an understanding of 'sustainability-as-practice'. Some have naturally taken a scientific approach (e.g. science-based disciplines) while others have emphasised more critical/phenomenological/cultural/political/ethical approaches (e.g. disciplines addressing international development, political economy, organisational studies, public health, social marketing and so on). We observed that aligning assessment strategies with the dialogical approach to understanding the problems, presents a challenge yet to be resolved. For example, the standard masters dissertation marking criteria favour traditional scientific methods over more reflexive methodologies (auto ethnography, thick description, hermeneutic enquiry), resulting in paradoxical and frustrating $2^{\text {nd }}$ marking/moderation outcomes.

ESD discussions within the institution have recently included debate about sustainability as a moralpolitical issue, challenging more instrumental sustainability practices such as, in the context of business and management, TBL (triple bottom line) accounting and reporting in both the curriculum and research and community projects. Such debate has led to reflection on what sustainable development might mean in professional practice, including management. For example, students are encouraged to understand the continuum between strong (deep ecological) and weak (anthropogenic or eco-efficiency driven) treatments of sustainability as well as the need to critically reflect on the processes of globalisation and economic-growth driven development positions. Paying attention to the issue of dominant Western knowledge and values in legitimising what counts as 'sustainability' knowledge is also encouraged, which has the potential to challenge the received wisdom of some disciplines. 


\subsection{The pedagogical axiom and responsible education for sustainable development}

The pedagogic axiom refers to the learning process. It is consideration of the learning process and the context in which learning takes place which distinguishes education for sustainable development from education about sustainable development. Key to the achievement of ESD outcomes is the engagement by the students in relevant learning activities. The goal is to enable students to develop the ability and intent to negotiate dilemmas posed by sustainable development, for example, how to mitigate the dominant needs of businesses to make profit whilst reducing global inequalities, ecological degradation and poverty. Consideration should be given to the provision of space for reflection vs normative theories (best practice prescriptions), contextual experiential learning, intuition, personal skills, emancipation and autonomy, situated reflexivity, historical nature of knowledge and identity, and cultural diversity. We have observed there to be ambiguity around what is considered as good practice (with questions of balance and appropriateness being central) and around the relative priority which should be afforded to differing values, views and performance indicators (both locally and globally) in the design of learning experiences. We see this as one of the key challenges in integrating ESD across the University.

Reference to external drivers is useful but our experience is that there is now too many frameworks and sets of criteria to enable those in the academic community who are new to ESD to quickly understand the context for ESD and the application of it to their own activities. UWE has recognised the value of and has supported pedagogic experimentation (with regard to approaches to the learning process, pedagogic aims and teaching methods). However, there remains a tension between teaching to learn, teaching for employability and teaching for student satisfaction. ESD has an ambition to meet all these important objectives of HE (see previous section), particularly when considered within the context of responsibility and sustainability in professional practice. In our view, the pedagogic axiom of ESD is heavily influenced by the organisational axiom (which will dictate some of the local values and KPIs by which pedagogy will be judged) but also intrinsically linked with the epistemic axiom (which is likely to be discipline - or professionally dictated).

UWE has taken very conscious action to align its educational provision to the principles of ESD and expectations of the QAA and HEA (2014) (Section 3). This has led to mandated engagement by academics with external ESD standards and the institution's ESD expectations. The content and delivery of teaching and learning is now reviewed with reference to ESD at module, programme and department level. This has led to changes in curriculum design and delivery in favour of approaches which include critical inquiry, experiential learning, and so on. However, as illustrated above, the systems of measuring students learning and development (marking criteria) lag behind in their flexibility to account for the emerging epistemic diversity.

\subsection{The social axiom and responsible education for sustainable development}

In the context of ESD, the social axiom could be seen as adjunct to the pedagogic axiom (and equally heavily influenced by the organisational axiom). This is particularly the case when we consider the context for learning and the social outcomes which are central to ESD (such as stewardship, responsibility, self-awareness and so on) and which have become pertinent in HE more generally, specifically in the context of employability. In UWE's ESD work, we have begun to explore ways in which professions may be affected by issues highlighted within the SDGs and how discipline-specific 
knowledge might contribute to the creation of more sustainable and just societies. Is knowledge (such as an academic degree informed by sustainability) a prerequisite for improved employability opportunities? What is the relationship between employability and responsible management education and how should it be recognised? These debates align to the vocational and critical components of Holman's (2000) social axiom.

UWE is working to ensure that these kinds of questions are being asked of all of our discipline areas. We believe that there is a case to be made that all HE is management education. We propose that all graduates have the capacity to be managers (in the broadest sense of the term). Whilst, we would not expect all graduates to become sustainability professionals, the qualities of a responsible manager sit comfortably alongside/within those of someone who is a future-facing, global citizen. This again highlights the relevance of management education to ESD and vice versa. Focusing on QAA-HEA promoted guidance on attributes (QAA-HEA, 2014) has enabled the institution to reflect on the values and aspirations which are resonate with developing cultivated global citizens, capable of leading 'personally fulfilling lives and help sustain a democratic and learned culture' (Holman, 2000, p.200). This sits firmly within the indirect cultural and critical components of the social axiom. Overall, we observed a direct social - cultural role of ESD: some courses have defined their learning outcomes as acquiring the knowledge, skills and ethical vocabulary necessary for encouraging critical dialogue, social advocacy and an active civic participation.

The social axiom is also complex and can be paradoxical because different roles (vocational, cultural, academic and critical) might inhibit and contradict each other (e.g. vocational versus academic). This is a sensitive issue and a challenge in an $\mathrm{HE}$ institution which is internationalised and where the classroom often replicates the diversity of the global world. How should we deal with the diversity (and, possibly, inequalities) in such a classroom and in the institution more broadly? One of the ways has been to take a scientific and /or functionalist, instrumental (presumed as value-free) view of sustainability but to facilitate and encourage debate about such positions. For example, we have been developing opportunities for interdisciplinary discussion by offering SD oriented modules to students from MBA, engineering, environmental science and consultancy MSc courses and forming teaching teams from across disciplines. Furthermore, during Bristol's year as Green Capital in 2015, UWE facilitated a large number of events which focused on issues set by the city as themes for the year (namely nature, transport, food, energy and resources). These gave staff and students from across UWE an opportunity to come together with other stakeholders from across Bristol to debate ways in which cities can be made more sustainable and the role of individuals and organisations in that process. Such interactions enable seamless integration of not only academic theory and practice, but all four components of the social axiom to be experienced simultaneously.

\subsection{The practice axiom and responsible education for sustainable development}

The practice axiom of ESD cannot be easily separated from the epistemic and organisational axioms. The challenge comes from trying to separate out sustainability-management-as-practice in the context of teaching and learning in HE from the context of professions in which graduates might in future be employed and from the context of the institutional management. In relation to teaching and learning in HE, the QAA, HEA, HEFCE and the National Union of Students (NUS) have all put forward the view that all disciplines (and possibly all academics) should be engaged in ESD. Our experience is that this is arguably the most challenging aspect of ESD in HE. In relation to the 
preparation of students to become sustainability-minded practitioners in their chosen field, we have identified the following dilemmas:

- What does it mean to educate students for sustainable development so that they can be successful practitioners and leaders towards a better world in each discipline/professional subject?

- What are the generic knowledge, skills and competencies of sustainability leaders/managers/professionals and how can these best be developed via educational provision?

- What is the relative significance of instrumental technical knowledge of problem-solving, or political rhetorical skills of persuasion or value-centred, action-oriented practical wisdom, which combines all other forms of knowledge with situational ethics in the local context?

Our evidence shows that the expectations from professional bodies (such as in architecture, civil engineering, project management, health and elsewhere) play an important role in how the above questions are addressed in curriculum design and delivery of higher education. Further, some students and academics assume an activist role and get involved in social advocacy initiatives. The role of practitioners in bringing the relevance of sustainability-in-practice to the classroom is valued and encouraged, as is the experience which students gain from other practice-oriented learning activities such as placements.

\subsection{The organisational axiom and responsible education for sustainable development}

The organisational axiom relates to autonomy and management of the institution but also to the accountability of educators. UWE has put significant effort over many years into making ESD more explicit and something that distinguishes our provision and/or the students' experiences from other graduates with similar degrees from other institutions. Critically, this position resonates with the sustainability focus which the institution has set for itself in its Sustainability Plan, which covers all aspects of our estate and our operations, including our educational provision. Our observation is that in this organisational axiom, a dominant set of assumptions and practices governs, constrains and re-produces the way the other axioms play out in relation to ESD. Much of the driving force behind institutional sustainability and ESD engagement is competition informed, so the level of autonomy exercised by the University over the process and content of ESD could easily be constrained by the requirement for greater accountability (e.g. QAA). However, UWE has exercised autonomy and taken action on sustainability before it was considered 'the norm' within HEIs. UWE was closely involved with the development of the QAA-HEA ESD guidance, has responded to sector and government consultations on ESD and signed up voluntary sustainability and ESD commitments, including receiving high praise from the NUS as part of its Responsible Futures accreditation.

In exploring our data, we identified the following examples of ways in which the organisation axiom (in our case representing institutional commitment to sustainability) has influenced ESD practice:

- the Vice Chancellor and his executive team have supported ESD engagement which in turn has empowered academics to embrace the ESD vision (creating a sustainability-as-practice environment and thus setting a context for the social axiom to play out); 
- championing of sustainability by the senior management team has enabled resources to be directed to staff and resource development activities and cross faculty collaboration (supporting the pedagogic axiom);

- introducing structural and operational changes to 'walk the talk' has enabled authentic encouragement of sustainable behaviour by staff and students in relation to teaching and learning and the staff and student experience (again supporting the management axiom by providing a precedent for tackling challenges where different levels of buy-in amongst staff have been experienced); and,

- institutional strategic commitment to partnerships, connections and networks has provided a platform from engaging with external communities, including during Bristol's year as European Green Capital in 2015 which enabled numerous ESD actions to be undertaken (supporting social/cultural, sustainability-as-practice and pedagogic axioms).

Within a large, complex institution like UWE, a whole spectrum of attitudes towards ESD exist ranging from instrumental environmental protection on one hand to more inquiry based and student-led pedagogic approaches with critical collaborative reflection on the other. With such diversity come a number of tensions. Multiple personal priorities and drivers must be recognised in order to achieve sustainability engagement across disciplines and services. Such diversity and richness provides a fertile ground for sustainability-driven innovation but there is potential for tension between the organisational axiom and this personal/discipline-based cultural context. UWE has been considering the contrast between what we (as an institution) expect of our students over the course of their development (knowledge, skills and competencies) and how UWE operate as an HEI. Rather than standardising the approach to achieving ESD outcome across an institution, it is most helpful to provide space and freedom within which diverse perspectives can be articulated and explored. The organisational commitment to agendas aligned to ESD has enabled the provision of such opportunities (including field trips, joint academic-student-practitioner conference presentations; engagement with the Green Capital; learning by walking and through evocative writing). This is where the organisational axiom becomes a critical enabler and/or constrainer of practice.

Despite strong strategy commitment and resource management and prioritisation in favour of sustainability, UWE has yet to commit to integrating accountability for sustainability action beyond those with direct sustainability responsibility. UWE have invested in the implementation of ISO14001: 2015 standards with a view of closing this gap by ensuring that responsibility for sustainability is distributed across the management structures of the institution but so far with unclear results.

\section{Critical experiences, practices and unresolved issues - A Discussion}

This section illuminates some interesting interdependences between the assumptions /axioms at play in our examination of practice at UWE, drawing attention to unique practices and prevailing assumptions behind ESD efforts, and the ways in which these have driven ESD practice. Three distinct educational approaches to ESD have been identified in the current UWE practice which reflect different priorities and positions on responsible (management) education for sustainability / 
SD which we will discuss in light of recommendations in the literature including Holman (2000). Areas for further work are also signposted.

The epistemological axiom seems to be integral to shaping, yet also be easily shaped by, all other groupings of assumptions when considered in the context of ESD. The 'subject' (sustainability/sustainable development) is indeed a fragmented value-laden field, so it becomes very difficult to agree and uniformly (cross-institutionally) prioritise key concerns. This has led, on the one hand, to an incoherent and often unconvincing argument being presented in the classroom. On the other hand, the nature of the 'subject' has allowed for experimental critical approaches to examining and uncovering the controversies around claimed coexistence of economic, ethical and ecological priorities. The underlying assumptions within the disciplinary fields are key, as is the notion of practice-relevant knowledge.

Sustainable development-as-practice is intrinsically and unavoidably linked to the epistemic axiom but significantly influenced by the strategic and competitive reality of the institution (organisational axiom). In the current culture of business engagement, the sustainability-as-practice axiom is very much influenced by external stakeholders.

The social axiom seems to have become inseparable from the pedagogic axiom with both being heavily influenced by the UWE context in the ways ESD has been understood and embraced by individuals, social structures and communities.

The pedagogical axiom appears to be heavily influenced by the organisational axiom but at the microlevel of course delivery reflects the 'local' epistemological and sustainability-as-practice set of assumptions.

In the context of ESD, the organisational axiom seems to impose a set of dominant assumptions and practices which, in many important ways, governs, constrains and re-produces all the other axioms including the way critical questions of the role of organisations in society, CSR and triple-bottom-line trade-offs are addressed. The accountability of management educators and an institutional reflection on what 'responsible' education for sustainable development means is a difficult area for action because of multiple lines of accountability and influence /power.

\subsection{Some practical possibilities and challenges for ESD}

Through our analysis we have identify three distinct models of engagement with ESD/RME coexisting at the University:

Approach 1 is designed and structured to facilitate the transmission of universally useful and applicable knowledge stemming from analytical thinking and scientific/instrumental sustainable development research. This model prioritises the achievement of learning outcomes as tangible and readily definable knowledge in line with economic, market and organisational requirements, or best practices as defined by professional bodies (competent and skilled human resources). It promotes ESD as vocationally very important (meeting economic and organisational requirements), good for employability and measurable (good for UWE reporting). The risk is that it reproduces a mainstream, instrumental view that we can manage our way out of the global and multifaceted sustainability crisis mainly through scientific and technological innovation. This approach gives 
primacy to, and legitimises certain epistemologies while marginalizing alternative responsible ways of knowing and dealing with the crisis of sustainable development. This model has benefits of being understood by the 'traditional academy' and is supported by metric-driven approaches to HE (organisational axiom).

Approach $\mathbf{2}$ is designed to engage with the complexity of sustainable development as a field of study and as practice in an indeterminate global context. Teaching and learning for sustainable development relies on direct input from practitioners (guest speakers from sustainability oriented and engaged organisations or from sustainability-related roles/responsibilities within practice). The key teaching input comes from the experience of action, reflection in action, and reconceptualisation, a result of passionate interaction with knowledge and focus on discursive plurality in practice. Teaching and research methods tend to privilege group work, sense making, psychosocial studies of group dynamics and reflexivity. This approach might not be seen to provide a direct vocational advantage, that is, a generic body of skills and knowledge for employability (such as meeting economic and organisational requirements, or best practices as defined by professional bodies) but exceptionally appreciated by the majority of students exposed to this mode and by experienced academics in related scholarly fields.

Approach 3 is closest to Holman's recommended model of education which recognises politicalsocial as well as scientific aspects of in 'fragmented fields' (such as SD, sustainability and management). It sharpens the students' sensitivity to how discourses support and marginalise certain truths and knowledge claims while silencing others. Grounded in a critical experiential / activist orientation (c.f Holman, 2000, pp.208-9) to ESD/RME it encourages questioning discursive power and hegemony ('received' wisdom, dominant epistemologies) in the curriculum, pedagogy and the institutional structures. It works best in classes combining participants from different subject departments (business, environmental sciences, engineering, psychology, etc.). This approach has been observed in instances of exceptional academic determination and engagement from all faculties at UWE and their strong individual and collective ability to influence the curriculum design and delivery. These powerful groups (with both status and influence) have been mainly developed through informal links supported by an inclusive, cross-University approach to UN PRME / ESD, above and beyond the confines of the University's business school, a vision actualised by, often spontaneous, formation of multidisciplinary cross-university teaching teams, Masters programmes and research and community projects. This in turn is largely down to educational activism at the academic level where power, status and enthusiasm, interdisciplinary collegiality and informal relationships across UWE have been combined to create syllabi discursively aligned with the institutional assumptions (Holman,2000; Hibbert, 2013; Cornuel, and Hommel, 2015; PainterMorland, 2015). The institution's explicit efforts to encourage networking and collaboration of likeminded scholars, external partners and students towards embedding ESD/RME have made an important difference - e.g., the students have been asked to evaluate and provide critical comments on the University's sustainability strategy as part of their respective curriculum.

Under the increasing wave of the financialisation and managerialisation of HE, ESD faces enormous challenges to reconcile what is desirable, effective and responsible with what is standardisable, internationally saleable, resource efficient, measurable, comparable and competitive. Holman (2000) and a number of other authors (Solitander, Fougère, Sobczak, and Herlin, 2012; Clegg and Ross- 
Smith, 2003; Trank and Rynes, 2003, Cicmil and Hodgson, 2007) have warned about an apparent conflict in the context of management education between the alternative approaches including epistemic/pedagogic pluralism and the agendas of institutional actors (managerialisation, standardisation, internationalisation) including business and media rankings, professional bodies, business schools and students. However, it is clear that HE is under pressure from many sources, both internal and external, to ensure that it fulfils its role of delivering teaching and learning and taking whatever action it can to encourage behaviour which aligns to the principles and objectives of sustainable development. The model of current practice (Approach $A$ ) is being challenged by external drivers including a need for students to develop the ability to adapt to and thrive in uncertain conditions, to innovate for the solution of 'wicked problems' and to act on the 'troublesome knowledge' relating to climate change and sustainable development. Students themselves are becoming increasingly vocal about their desire for a different kind of education.

Alternative identified approaches 2 and 3 are grounded in research methodologies which embrace critical existential phenomenology, ethnography and anthropology, cultural studies and similar. Outcomes include the ability of an individual to be reflexive about their own knowing and doing; to apply situational ethics; to demonstrate social and political virtuosity developed from experience by reflection and action. Although not widely present across the institution, we have come across a few considerably successful examples of this (evidenced by students' exceptionally positive feedback and employment destinations), particularly in the disciplines related to organisational management, human geography, arts and politics. One of our MSc students said about his sustainability related educational experience: "My learning and practice [have been] an act of creation, founded in a profound love of the world and the people who inhabit it, whilst simultaneously recognising the incompleteness of my own understanding as I continue to attempt to learn more than I now know about this complex subject".

\section{Conclusions and Propositions}

An objective of this paper was to use Holman's axioms to identify more clearly-defined directions or frameworks for embedding ESD, a need for which has been expressed by academics, particularly those less familiar with ESD. Striving for a kind of uniform, widely accepted and agreed way of talking about sustainability across UWE, has previously proven to be a difficult task and, possibly, rather unhelpful. A closer examination of the interrelationships between these dynamic sets of assumptions and of the micro-diversity in the context of their implementation, has highlighted important challenges where a dialogical approach among involved groups / stakeholders is required to overcome them. Making the values and ideologies transparent when explaining epistemic diversity and recognising the need for sensemaking and multiple definitions of S/SD seem to be better, more liberating and genuine approaches which can be most effectively facilitated by promoting a dialogue and dialogical knowledge creation among the students, the academics, employers, University management and other stakeholders. There is an increasing understanding that big businesses, global institutions and governments play a significant role in defining both the sustainable development challenge and the work to find solutions, including the engagement of higher education. 
In the spirit of PRME, we wish to open up space for a dialogue and debate about prospects and possible developments of responsible management education in the future, and particularly how those would both shape and be shaped by the changing context and priorities of higher education including the imperatives of SDGs and ESD. Using practical theorising based on related literature and concrete empirical analysis, we have in this paper a) adapted Holman's original framework of 5 axioms of management education into a helpful analytical tool for examination of ESD; b) illuminated some interesting and informative interdependences between the axioms drawing attention to unique practices and prevailing assumptions in the context of ESD and RME efforts at a UK University, c) drawn some practical and theoretical conclusions about inseparability of, in particular, the organisational axiom of the institution, the dominant view about sustainability management-as-practice and local pedagogic innovations and d) critically evaluated three empirically identified approaches to embedding SD/PRME and signposted directions for further research into how the notion of 'responsible education' is to be understood in the context of ESD.

With reference to Table 2 and Section 4, we argue that Holman (2000) seems to have offered a tool for making sense of what is recognised to be a 'fragmented field' (ibid., p.209) and which has enabled us to identify dominant influences shaping ESD practice and provision (Section 5). Embedding ESD responsibly across a HE institution is a complex, emerging, evolving and non-linear process of addressing simultaneously the curriculum content, power, structures, identity, values, and external checks and balances. In the unique case of the studied university, where PRME and ESD have been embraced simultaneously, we have identified three approaches including emerging alternative ones (Approaches 2 and 3 ) involving action and reflection. Approach 3 to ESD seems to be specifically grounded in participatory educational activism presenting an alternative to the pedagogic status quo, informal academic collaboration, formal measures and reporting, and practical skills of maintaining legitimacy and ownership of creative and innovative pedagogic models while negotiating the meaning of those to align with the institutional priorities. A deeper examination (see previous section) demonstrates that a responsible cross-institutional engagement with PRME (purpose, values, method, research, dialogue and partnership) enables the actualisation of this approach and its possibilities. With reference to Painter-Morland (2015) we believe that further study is needed to investigate whether such cross-institutional engagement can be done by design and training or whether it should be nurtured as an organic, emerging, self-selection based process deeply rooted in not only academic position but personal-moral views.

Overall, UWE organisational assumptions tend to reflect the position that managerialist practices are appropriate and unproblematic. Interestingly, the above mentioned interdependence between the axioms generates contradictions or conflicts between some of them, largely indicated by the drive for greater vocationalism, and managerialisation and reduced resources at the institutional level. These contradictions are often negotiated at a local level through a spontaneous regrouping, collaboration, solidarity and pride among like-minded academics in experimenting with what they believe is best for the students and communities, sometimes in spite of institutional direction. In the context of ESD, this might be explained as a prioritisation of Approach 3 (above) in the face of organisational direction akin to Approach 1.

\subsection{Next steps}


In pursuing our proposition at a juncture where society is facing a sustainability crisis across borders, we can identify scope for further evaluation and action. Firstly, we would suggest that more work be done to better understand the organisational context (the organisational axiom ) for implementation of ESD from an HE perspective. The principles and guidance produced at national and international level, whilst critical for developing understanding of the objectives of ESD and methods (pedagogic axiom) which might lead to achievement of such objectives, do not include consideration of the political and cultural context in which ESD must sit within HE. The sector must consider how it might shift from a model of organisational dominance to one of sustainability-aspractice context if it is to demonstrate a deeper level of engagement with ESD and responsible management.

Secondly, it would be important to go beyond Holman's work and explicitly address the international make-up of a contemporary university. The challenges and opportunities posed by the increasingly internationally diverse profile of both student and staff communities is also relevant here. Moreover, greater attention needs to be paid to the complexities associated with the process of globalisation, micro-diversity, culture, ethics, history, the human condition and epistemic plurality in the context of both responsible management education and ESD more generally. We argue that the social axiom of education for sustainability (as analysed in this paper) should be given more prominent attention given its pivotal role in exploring the meaning and application of 'responsible' management education (or education of responsible managers, which aligns well to the objectives of ESD).

Finally, given the emerging rhetoric (in sustainability management, in HE and in business) of devolved responsibility and greater accountability, more clarity is needed to identify who is or should be responsible to whom and for what? How is responsibility (for ESD and responsible management education) shared in the HE context? The role of dialogue, partnerships, and transparency that support the requisite epistemic freedom and co-existence of different (and sometimes conflicting) viewpoints on the complex and fragmented concepts embedded in sustainable development would seem significant. Thus we propose that there is a need to revisit the purpose, value and nature of $\mathrm{HE}$ in contributing to positive global development and the role of the academic in meeting this purpose. Such a process must involve all stakeholders, particularly HE managers, academics and students if systems are to change in favour of structures which permit greater fluidity between disciplines and roles. 


\section{References:}

Burchell, J., Kennedy, S. and Murray, A. (2015) 'Responsible management education in UK business schools: Critically examining the role of the United Nations Principles for Responsible Management Education as a driver for change', Management Learning, 46(4), pp. 479-497.

Cicmil, S. and Hodgson, D. (2007) 'Risks of innovation in management education: Introducing a critical management perspective onto a project management MBA elective' IRNOP XII Conference (International Research Network on Projects) : Projects in Innovation, Innovation in Projects, $19^{\text {th }}-21^{\text {st }}$ September 2007, Brighton, UK http://eprints.uwe.ac.uk/16880

Cicmil, S., Ecclestone, R. and Collins, K. (2017) 'Responsible education in a complex context of sustainable development: Co-creating a pedagogic framework for participatory reflection and action', in: Flynn, P., Gudic, M. and Tan, T K., eds., 'Redefining Success: Integrating the UN Global Compact into Management Education'. Saltaire, UK: Greenleaf Publishing [forthcoming].

Clegg, S.R. and Ross-Smith, A. (2003) "Revising the Boundaries: Management Education and Learning in a Postpositivist World", Academy of Management Learning \& Education, 2(1), pp. 85-98.

Cornuel, E. and Hommel, U. (2015) 'Moving beyond the rhetoric of responsible management education', Journal of Management Development, 34(1), pp. 2-15.

Curry, P. (2011) Ecological Ethics $2^{\text {nd }}$ ed. Cambridge: Polity Press.

Eady, S., Drew, V. and Smith, A. (2015) 'Doing action research in organizations: Using communicative spaces to facilitate (transformative) professional learning', Action Research, 13(2), pp. 105122.

Flyvbjerg, B. (2001) Making Social Science Matter: Why social inquiry fails and how it can succeed again (reprinted 2003); Cambridge University Press: Cambridge

Flyvbjerg, B. (1998) Rationality and Power: Democracy in Practice, University of Chicago Press: London

Gladwin, T., Kennelly, J and, Krause, T-S. (1995) 'Shifting Paradigms for Sustainable Development: Implications for Management Theory and Research', Academy of Management Review 20(4): 874-907.

Godemann, J., Haertle, J., Herzig, C. and Moon, J. (2014) 'United Nations supported Principles for Responsible Management Education: purpose, progress and prospect', Journal of Cleaner Production, 62, pp. 16-23.

Hibbert, P. (2013) 'Approaching Reflexivity Through Reflection: Issues for Critical Management Education', Journal of Management Education, 37(6), pp. 803-827.

Higher Education Funding Council for England (HEFCE), 2014, Sustainable development in higher education: HEFCE's role to date and a framework for its future actions, HEFCE, Bristol. 
Holman, D. (2000) 'Contemporary models of Management Education in the UK' Management Learning, 31 (2): 197-217

Hutchings, K. (2010) Global Ethics - An Introduction. Cambridge: Polity Press.

Introna, L.D. (1997) Management, Information, and Power, Macmillan Press: London

Karakas, F., Sarigollu, E. and Manisaligil, A. (2013) 'The use of benevolent leadership development to advance principles of responsible management education', Journal of Management Development, 32(8), pp. 801-822.

Louw, J. (2015) "'Paradigm Change" or No Real Change At All? A Critical Reading of the U.N. Principles for Responsible Management Education', Journal of Management Education, 39(2), pp. 184-208.

Painter-Morland, M. (2015) 'Philosophical assumptions undermining responsible management education', Journal of Management Development, 34(1), pp. 61-75.

Painter-Morland, M., Sabet, E., Molthan-Hill, P., Goworek, H. and de Leeuw, S. (2016) 'Beyond the Curriculum: Integrating Sustainability into Business Schools', Journal of Business Ethics, 139(4), pp. 737-754.

Quality Assurance Agency for Higher Education (QAA) and the Higher Education Academy (HEA), 2014, Education for sustainable development: Guidance for UK higher education providers, Quality Assurance Agency for Higher Education, Gloucester.

Segal, S., Rolfe, B. and Cicmil, S. (2016) 'An Existential Hermeneutic Philosophical Approach to Project Managing' Project Management Journal 47(3) (in press).

Solitander, N., Fougère, M., Sobczak, A. and Herlin, H. (2012) 'We Are the Champions: Organizational Learning and Change for Responsible Management Education', Journal of Management Education, 36(3), pp. 337-363.

Trank, C.Q. and Rynes, S.L. (2003) "Who Moved Our Cheese? Reclaiming Professionalism in Business Education", Academy of Management Learning \& Education, 2(2), pp. 189-205.

United Nations Education Scientific and Cultural Organisation (UNESCO), 2016, Education for Sustainable Development (online), http://en.unesco.org/themes/education-sustainabledevelopment last accessed November 2016)

United Nations Education Scientific and Cultural Organisation (UNESCO) (2014a) Shaping the Future We Want: UN Decade of Education for Sustainable Development (2005-2014) Final Report, UNESCO, Paris.

United Nations Education Scientific and Cultural Organisation (UNESCO) (2014b) UNESCO Roadmap for Implementing the Global Action Programme on Education for Sustainable Development, UNESCO, Paris. 
University of the West of England (2016) Strategy 2020, UWE, Bristol. Available online at: http://www1.uwe.ac.uk/about/corporateinformation/strategy.aspx

University of the West of England (2013) Positive footprint: phase 2. UWE Bristol Sustainability Plan 2013 - 2020, UWE, Bristol. Available online at:

http://www1.uwe.ac.uk/about/corporateinformation/strategy/strategydocuments.aspx. 